\title{
PEMODELAN MATEMATIS UNTUK PERSAMAAN BEDA POTENSIAL LISTRIK
}

\author{
Resti Julia Susanti, Evi Noviani, Fransiskus Fran
}

\begin{abstract}
INTISARI
Pada penelitian ini, permasalahan beda potensial listrik pada sebuah muatan listrik positif yang diukur pada sebarang titik $(x, y)$ terhadap titik asalnya yakni titik $\left(x_{0}, y_{0}\right)$ dimodelkan ke dalam persamaan diferensial. Model untuk persamaan beda potensial listrik diperoleh dengan menggunakan konsep-konsep yang mendasari elektrostatis yaitu persamaan medan listrik, fluks listrik, hukum Coulomb dan hukum Gauss. Dengan melambangkan potensial listrik sebagai $V$, rapat muatan sebagai $\sigma$, dan konstanta listrik sebagai $\varepsilon_{0}$, beda potensial listrik dapat dituliskan ke dalam bentuk persamaan Poisson yakni $\frac{\partial^{2} V}{\partial x^{2}}+\frac{\partial^{2} V}{\partial y^{2}}=-\frac{\sigma}{\varepsilon_{0}}$. Misalkan titik asal muatan listrik tersebut adalah titik (0,0), maka dengan menggunakan konsep fungsi delta, persamaan diferensial untuk beda potesial listrik dituliskan sebagai $\frac{\partial^{2} V}{\partial x^{2}}+\frac{\partial^{2} V}{\partial y^{2}}=-\frac{q}{\varepsilon_{0}} \delta(x, y)$.
\end{abstract}

Kata Kunci: persamaan beda potensial listrik, fungsi delta, listrik statis.

\section{PENDAHULUAN}

Salah satu permasalahan dalam fisika yang dapat dimodelkan ke dalam persamaan diferensial parsial adalah listrik statis. Listrik statis adalah istilah yang digunakan untuk muatan listrik yang tidak mengalir. Dalam kehidupan sehari-hari, listrik statis dapat memberikan keuntungan maupun kerugian. Keuntungan yang diperoleh dari listrik statis contohnya pada penggunaan cat semprot untuk mewarnai mobil. Pada ujung alat penyemprot diproduksi ion-ion dengan memberikan tegangan listrik yang sangat tinggi. Material pelapis atau cat didorong dengan udara dan saat melewati ujung nozzle, cat menangkap sedikit muatan sehingga menjadi partikel bermuatan. Bahan yang dilapis atau dicat umumnya adalah konduktor yang diberikan muatan berlawanan tanda. Partikel pelapis yang telah bermuatan ditarik oleh muatan di permukaan bahan yang akan dicat sehingga jatuh ke permukaan tersebut secara merata. Sedangkan kerugian yang diakibatkan oleh listrik statis contohnya menyebabkan petir dan percikan api pada ban mobil atau truk akibat gesekan dengan jalan [1].

Listrik statis merupakan fenomena yang terjadi akibat ketidakseimbangan muatan pada suatu benda. Ketidakseimbangan muatan terjadi karena benda bergesekan dengan benda lainnya dan menyebabkan benda tersebut menjadi bermuatan listrik. Listrik statis yang dihasilkan akibat gesekan antar benda disebut sebagai elektrostatis. Salah satu bagian dari elektrostatis yang dapat dikaji dalam matematika adalah beda potensial listrik. Beda potensial listrik merupakan usaha yang diperlukan untuk memindahkan muatan listrik dari suatu titik ke titik lainnya.

Persamaan beda potensial listrik pada penelitian ini dimodelkan secara matematis ke dalam bentuk persamaan diferensial dua dimensi. Oleh karena itu, dalam penelitian ini dibahas mengenai bagaimana memodelkan beda potensial listrik ke dalam persamaan diferensial parsial. Pembahasan tersebut dibatasi pada persamaan diferensial dalam dua dimensi saja dan muatan yang digunakan untuk pemodelan adalah muatan listrik pada satu partikel.

Pada penelitian ini, untuk memperoleh model matematis dari persamaan beda potensial listrik terlebih dahulu dimisalkan terdapat suatu muatan tunggal pada titik $\left(x_{0}, y_{0}\right)$ dan menganalisa persamaan fluks listrik yang dihasilkan oleh muatan tersebut. Setelah diperoleh persamaan untuk fluks listrik, selanjutnya dapat dicari persamaan untuk medan listrik yang dihasilkan oleh muatan tersebut dan menuliskan persamaan medan listrik yang telah diperoleh ke dalam bentuk persamaan diferensial. 
Dengan menggunakan teori yang mendasari elektrostatis yakni hubungan antara medan listrik dan potensial listrik maka didapatkan model matematis untuk persamaan beda potensial listrik.

\section{KONSEP YANG MENDASARI ELEKTROSTATIS}

Elektrostatis adalah listrik statis yang timbul akibat gesekan antar benda. Elektrostatis didasari oleh beberapa konsep yakni muatan listrik, medan listrik, fluks listrik, potensial listrik, hukum Gauss dan hukum Coulomb [2].

Konsep yang paling mendasar dalam elektrostatis adalah adanya muatan listrik. Muatan listrik adalah partikel dasar yang membangun suatu objek dan terdapat pada suatu benda di mana pun benda tersebut berada. Terdapat dua jenis muatan listrik yakni muatan listrik positif dan muatan listrik negatif. Muatan listrik dilambangkan dengan $q$ dan satuan dari muatan listrik adalah Coulomb yang dilambangkan dengan $C$.

Apabila dua buah muatan listrik didekatkan satu sama lain pada jarak tertentu, maka kedua muatan ini akan menghasilkan gaya yang disebut sebagai gaya elektrostatis atau gaya Coulomb. Gaya elektrostatis dijabarkan dalam hukum Coulomb yang menyatakan bahwa "Besar gaya tarik menarik atau tolak menolak antara dua benda bermuatan listrik berbanding lurus dengan besar muatan masingmasing benda dan berbanding terbalik dengan kuadrat jarak kedua benda tersebut". Hukum Coulomb dirumuskan sebagai berikut:

dengan

$$
\vec{F}=\frac{1}{4 \pi \varepsilon_{0}} \frac{q_{1} q_{2}}{r^{2}} \hat{r}
$$

$\vec{F} \quad$ : Gaya Coulomb atau gaya elektrostatis (Newton)

$q_{1} \quad$ : Muatan listrik 1 (Coulomb)

$q_{2}:$ Muatan listrik 2 (Coulomb)

$\varepsilon_{0} \quad:$ Konstanta listrik $\left(8,8 \times 10^{-12}\right.$ Farad per meter $)$

$r \quad:$ Jarak antar muatan $q_{1}$ dan $q_{2}$ (meter)

$\hat{r} \quad$ : Vektor perpindahan dari titik muatan $q_{1}$ ke titik muatan $q_{2}$.

Setiap muatan listrik menghasilkan sesuatu yang memengaruhi ruang di sekitar muatan listrik tersebut berada. Sesuatu yang dihasilkan oleh muatan listrik ini disebut sebagai medan listrik. Pengaruh dari medan listrik hanya dirasakan oleh muatan listrik lain disekitarnya. Medan listrik dirumuskan sebagai berikut:

$$
\vec{E}=\frac{\vec{F}}{q}
$$

dengan

$\vec{E} \quad:$ Medan listrik $(N / C)$

$q \quad$ : Muatan listrik (Coulomb).

Bentuk visualisasi dari medan listrik disebut sebagai fluks listrik. Fluks listrik juga didefinisikan sebagai ukuran aliran medan listrik yang melalui sebuah permukaan dan divisualisasikan sebagai garis-garis medan listrik yang mengarah menjauhi muatan listrik positif dan mendekati muatan listrik negatif. Fluks listrik dirumuskan sebagai berikut:

dengan

$$
\Phi=\vec{E} \cdot \vec{A}
$$

$\Phi \quad:$ Fluks listrik $\left(\mathrm{Nm}^{2} / \mathrm{C}\right)$

$\vec{E} \quad$ : Medan Listrik $(N / C)$

$\vec{A} \quad$ : Luas permukaan Gauss $\left(\mathrm{m}^{2}\right)$.

Untuk mempermudah dalam menghitung fluks listrik yang dihasilkan oleh suatu muatan listrik digunakan permukaaan Gauss. Permukaan Gauss adalah permukaan tertutup tiga dimensi yang bersifat simetri. Permukan Gauss merupakan permukan khayal yang digambarkan melingkupi sejumtaht 
muatan dan fluks listrik mengalir menembus permukaan tersebut. Hubungan antara permukaan Gauss dan fluks listrik dijabarkan dalam hukum Gauss yang menyatakan bahwa "total fluks listrik yang melalui suatu permukaan tertutup sebanding dengan total muatan yang terlingkupi oleh permukaan tersebut". Hukum Gauss dirumuskan sebagai berikut:

$$
\varepsilon_{0} \Phi=Q
$$

Lambang $Q$ pada persamaan (2) melambangkan total muatan yang terlingkupi oleh permukaan Gauss.

Setiap muatan listrik yang berada pada suatu titik memiliki energi potensial yang disebut sebagai potensial listrik. Potensial listrik juga didefinisikan sebagai energi potensial listrik per satuan muatan listrik, yang dirumuskan sebagai berikut:

$$
V_{a}=\frac{E P_{a}}{q}
$$

dengan

$V_{a} \quad$ : Potensial listrik pada titik $a$ (Volt)

$E P_{a} \quad$ : Energi potensial pada titik $a$ (Joule).

Berdasarkan hubungannya dengan medan listrik, beda potensial listrik dapat dinyatakan sebagai berikut:

$$
V_{b}-V_{a}=-\int_{a}^{b} \vec{E} \cdot d \vec{l},
$$

dengan $l$ menyatakan panjang lintasan muatan dari titik $a$ ke titik $b$.

\section{PERSAMAAN DIFERENSIAL PARSIAL}

Berikut adalah definisi-definisi terkait persamaan diferensial parsial:

Definisi 1 [3] Misalkan $u=u(x, y)$ merupakan fungsi dengan dua variabel. Sebuah persamaan yang berbentuk

$$
F\left(x, y, u, u_{x}, u_{y}, u_{x x}, u_{x y}, \ldots\right)=0 \text {, }
$$

disebut sebagai persamaan diferensial parsial.

Definisi 2 [3] Solusi dari suatu persamaan diferensial parsial

$$
F\left(x, y, u, u_{x}, u_{y}, u_{x x}, u_{x y}, u_{y y}, \ldots\right)=0,
$$

adalah suatu fungsi $u(x, y)$ yang memenuhi persamaan tersebut.

Pada penelitian ini, persamaan beda potensial listrik dimodelkan ke dalam bentuk persamaan Poisson, yang didefinisikan sebagai berikut [3]:

$$
\Delta u=f \text {. }
$$

Lambang $f$ merupakan suatu fungsi atau konstanta dan $\Delta$ merupakan operator Laplace. Dikarenakan beda potensial listrik pada penelitian ini dimodelkan ke dalam persamaan diferensial parsial dua dimensi, maka operator Laplace yang digunakan didefinisikan sebagai berikut:

$$
\frac{\partial^{2}}{\partial x^{2}}+\frac{\partial^{2}}{\partial y^{2}}
$$

\section{FUNGSI DELTA}

Fungsi delta dicetuskan oleh Dirac pada tahun 1926, yakni fungsi yang bernilai nol kecuali pada titik sumbernya dan integral fungsi delta sepanjang interval domainnya adalah sama dengan satu. Pada penelitian ini penggunaan fungsi delta bertujuan untuk menunjukkan letak muatan listrik tunggal yang berada di dalam suatu volume atau luasan pada titik sumbernya. Selanjutnya fungsi delta digunakan untuk memodelkan bagian nonhomogen dari persamaan beda potensial listrik yang telah diperoleh dalam bentuk persamaan Poisson. Fungsi delta secara matematis dituliskan sebagai berikut [4]: 


$$
\delta\left(x-x_{0}\right)=\left\{\begin{array}{l}
0 ; x \neq x_{0} \\
\infty ; x=x_{0}
\end{array}\right.
$$

Berikut adalah sifat fungsi delta:

$$
\begin{aligned}
& \text { 1. } \int_{-\infty}^{\infty} \delta\left(x-x_{0}\right) d x=1 \\
& \text { 2. } \int_{-\infty}^{\infty} f(x) \delta\left(x-x_{0}\right) d x=f\left(x_{0}\right) \text {. }
\end{aligned}
$$

Fungsi delta dalam dua dimensi didefinisikan sebagai berikut [5]:

$$
\delta\left(x-x_{0}, y-y_{0}\right)=\left\{\begin{array}{c}
0 ;(x, y) \neq\left(x_{0}, y_{0}\right) \\
\infty ;(x, y)=\left(x_{0}, y_{0}\right)
\end{array} .\right.
$$

Sifat fungsi delta pada dimensi dua adalah

$$
\begin{aligned}
& \text { 1. } \int_{-\infty}^{\infty} \int_{-\infty}^{\infty} \delta\left(x-x_{0}, y-y_{0}\right) d x d y=1 \\
& \text { 2. } \int_{-\infty}^{\infty} \int_{-\infty}^{\infty} f(x, y) \delta\left(x-x_{0}, y-y_{0}\right) d x d y=f\left(x_{0}, y_{0}\right)
\end{aligned}
$$

\section{MODEL BEDA POTENSIAL LISTRIK DALAM BENTUK PERSAMAAN DIFERENSIAL}

Misalkan terdapat suatu partikel bermuatan listrik positif yang dilambangkan dengan $q_{+}$. Langkah awal untuk memperoleh persamaan beda potensial listrik untuk muatan $q_{+}$adalah mencari persamaan medan listrik yang dihasilkan oleh muatan tersebut.

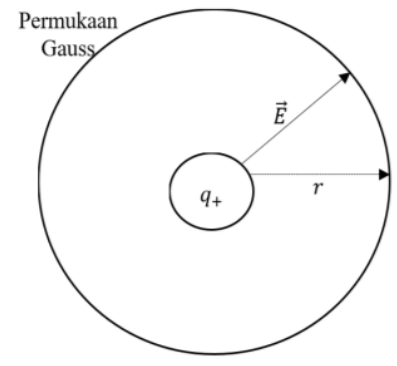

Gambar 1. Permukaan Gauss Pada Muatan $q_{+}$

Untuk memperoleh persamaan medan listrik yang diakibatkan oleh muatan $q_{+}$maka terlebih dahulu dicari fluks listriknya. Untuk itu, dimisalkan terdapat permukaan Gauss yang melingkupi muatan tersebut seperti pada Gambar 1. Misalkan permukaan Gauss tersebut berbentuk bola dan dinamai permukaan $A$. Untuk menghitung fluks listrik yang dihasilkan pada permukaan $A$ maka permukaan tersebut dibagi menjadi potongan-potongan kecil dan digambarkan terdapat vektor $d \vec{A}$ yang tegak lurus menembus potongan tersebut. Vektor $d \vec{A}$ menggambarkan arah fluks listrik yang dihasilkan oleh muatan $q_{+}$. Karena $q_{+}$bermuatan positif, maka vektor $d \vec{A}$ mengarah keluar atau mengarah menjauhi muatan $q_{+}$. Ilustrasi dapat dilihat pada Gambar 2.

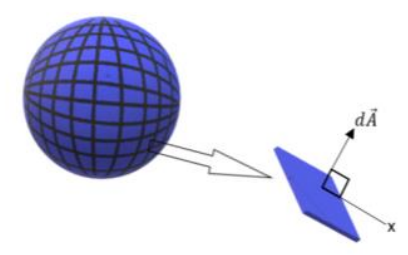

Gambar 2. Vektor $d \vec{A}$ Pada Permukaan $\alpha A$ 
Fluks listrik yang dihasilkan oleh muatan $q_{+}$dapat dihitung dengan menggunakan persamaan (1). Perhatikan bahwa luas permukaan $A$ dapat dihitung dengan menggunakan integral sehingga persamaan (1) dapat dituliskan sebagai berikut:

$$
\Phi=\int_{A} \vec{E} \cdot d \vec{A}
$$

Medan listrik yang dihasilkan oleh muatan $q_{+}$diperoleh dengan mensubstitusikan persamaan (5) ke dalam hukum Gauss pada persamaan (2) sehingga didapat

$$
\varepsilon_{0} \int_{A} \vec{E} \cdot d \vec{A}=Q
$$

dengan $Q$ melambangkan total muatan yang dilingkupi oleh permukaan $A$. Karena muatan yang berada di dalam permukaan $A$ adalah muatan $q_{+}$dan arah medan listrik sejajar dengan arah fluks listrik yang dihasilkan oleh muatan $q_{+}$maka persamaan (6) dapat dituliskan sebagai berikut:

$$
\varepsilon_{0} \int E d A=q .
$$

Integral pada persamaan (7) menunjukkan luas permukaan $A$. Karena permukaan $A$ berbentuk permukaan bola dan luas permukaan bola adalah $4 \pi r^{2}$, dengan mensubstitusikan $4 \pi r^{2}$ ke persamaan (7), maka diperoleh

$$
\begin{aligned}
\varepsilon_{0} E 4 \pi r^{2} & =q \\
E & =\frac{1}{4 \pi \varepsilon_{0}} \frac{q}{r^{2}} .
\end{aligned}
$$

Persamaan (8) merupakan rumus untuk besarnya medan listrik yang dihasilkan oleh muatan $q_{+}$.

Untuk memperoleh model beda potensial listrik dalam bentuk persamaan diferensial, maka rumus medan listrik akibat muatan $q_{+}$pada persamaan (8) terlebih dahulu diubah ke dalam bentuk persamaan diferensial. Misalkan muatan listrik terletak dalam suatu konduktor dengan volume sebesar $V$, maka total muatan $Q$ pada volume tersebut dapat ditulis sebagai berikut [2]:

$$
Q=\int \rho_{v} d V
$$

dengan $\rho_{v}$ melambangkan rapat muatan pada volume $V$. Substitusikan persamaan (9) ke persamaan hukum Gauss pada persamaan (2) sehingga hukum Gauss menjadi:

$$
\varepsilon_{0} \Phi=\int \rho_{v} d V
$$

Selanjutnya substitusikan persamaan total fluks listrik pada persamaan (6) ke persamaan (10) sehingga diperoleh hubungan antara medan listrik dan hukum Gauss yakni

$$
\varepsilon_{0} \int \vec{E} \cdot d \vec{A}=\int \rho_{v} d V
$$

Dengan mengaplikasikan teorema divergensi Gauss maka diperoleh

$$
\varepsilon_{0} \int \vec{E} \cdot d \vec{A}=\varepsilon_{0} \int \nabla \cdot \vec{E} d V
$$

Substitusikan persamaan (12) ke persamaan (11) sehingga diperoleh persamaan diferensial medan listrik yaitu

$$
\begin{aligned}
\varepsilon_{0} \int \nabla \cdot \vec{E} d V & =\int \rho_{v} d V \\
\varepsilon_{0}(\nabla \cdot \vec{E}) & =\rho_{v}
\end{aligned}
$$




$$
\nabla \cdot \vec{E}=\frac{\rho_{v}}{\varepsilon_{0}}
$$

Lambang $\nabla$ merupakan lambang operator del yang didefinisikan sebagai berikut:

$$
\frac{\partial}{\partial x}+\frac{\partial}{\partial y}
$$

Persamaan (13) merupakan persamaan diferensial untuk medan listrik dengan $\vec{E}$ melambangkan vektor medan listrik, $\rho_{v}$ melambangkan rapat muatan listrik dan $\varepsilon_{0}$ melambangkan konstanta listrik.

Selanjutnya, untuk memperoleh persamaan diferensial beda potensial listrik maka digunakanlah hubungan antara medan listrik dan potensial listrik pada persamaan (4). Dengan mengaplikasikan teorema dasar integral garis, ruas kiri persamaan (4) dapat dituliskan sebagai berikut:

$$
V_{b}-V_{a}=\int_{a}^{b} \nabla \mathrm{V} \cdot d \vec{l}
$$

Dengan mensubstitusikan persamaan (14) ke persamaan (4), maka didapatlah hubungan antara medan listrik dan potensial listrik dalam bentuk persamaan diferensial.

$$
\begin{aligned}
\int_{a}^{b} \nabla \mathrm{V} \cdot d \vec{l} & =-\int_{a}^{b} \vec{E} \cdot d \vec{l} \\
-\nabla V & =\vec{E} .
\end{aligned}
$$

Substitusikan persamaan (13) ke persamaan (15), sehingga diperoleh

$$
\begin{aligned}
\frac{\rho_{v}}{\varepsilon_{0}} & =\nabla \cdot \vec{E}=\nabla \cdot(-\nabla V) \\
\Delta V & =-\frac{\rho_{v}}{\varepsilon_{0}} .
\end{aligned}
$$

Persamaan (16) merupakan persamaan diferensial untuk beda potensial listrik. Berdasarkan persamaan (3), besarnya potensial listrik pada titik $a$ dirumuskan sebagai berikut:

$$
V_{a}=\frac{E P_{a}}{q}
$$

Apabila muatan titik $q$ berpindah dari suatu titik $a$ ke titik $b$, maka beda potensialnya dapat ditulis sebagai berikut:

$$
V_{a b}=\frac{E P_{b}-E P_{a}}{q}=\frac{W_{a b}}{q} .
$$

Lambang $W_{a b}$ menunjukkan usaha untuk memindahkan muatan titik $q$ dari $a$ ke $b$. Usaha dirumuskan sebagai perkalian antara gaya dan perpindahan. Oleh karena gaya yang bekerja pada muatan listrik adalah gaya Coulomb, maka persamaan (17) dapat ditulis sebagai berikut:

$$
\begin{aligned}
V_{a b} & =\frac{W_{a b}}{q}=\frac{\vec{F} r}{q} \\
& =\frac{\vec{E} q r}{q} \\
& =\frac{1}{4 \pi \varepsilon_{0}} \frac{q}{r} .
\end{aligned}
$$

Lambang $r$ pada persamaan (18) menunjukkan perpindahan muatan $q$ dari titik awalnya. Dimisalkan titik awal muatan $q$ adalah titik $(0,0)$ dan muatan titik $q$ dapat berpindah kesegala arah sepanjang $r$ seperti pada Gambar 3. 


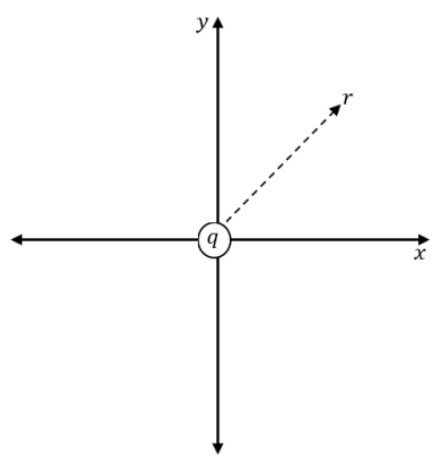

Gambar 3. Perpindahan Muatan $q$ dari Titik $(0,0)$ Sejauh $r$

Dari persamaan (18) dapat dilihat bahwa beda potensial listrik berbanding terbalik dengan jauh perpindahannya. Sehingga diperoleh hubungan, semakin jauh perpindahan suatu muatan listrik maka semakin kecil beda potensialnya, yang dituliskan sebagai berikut:

$$
\left.V\right|_{\sqrt{x^{2}+y^{2} \rightarrow \infty}}=\left.\frac{\partial V}{\partial x}\right|_{\sqrt{x^{2}+y^{2}} \rightarrow \infty}=\left.\frac{\partial V}{\partial y}\right|_{\sqrt{x^{2}+y^{2} \rightarrow \infty}}=0 .
$$

Persamaan (19) merupakan kondisi awal untuk persamaan beda potensial listrik.

\section{HUBUNGAN RAPAT MUATAN DAN FUNGSI DELTA}

Berdasarkan persamaan beda potensial listrik pada persamaan (13), apabila muatan listrik berada pada suatu luasan, maka rapat muatan $\rho_{v}$ dapat dilambangkan sebagai $\sigma$, yang menyatakan rapat muatan per satuan luas. Oleh karena itu, persamaan (13) dituliskan sebagai berikut:

$$
\Delta V=-\frac{\sigma}{\varepsilon_{0}}
$$

Fungsi delta digunakan untuk menggambarkan suatu fungsi yang bernilai nol pada semua titik kecuali pada titik $x=0$ atau yang disebut sebagai titik sumber. Misalkan muatan listrik berdistribusi pada suatu luasan sebesar $A$, maka total muatan pada luasan tersebut dapat dituliskan dalam bentuk integral yakni sebagai berikut [2]:

$$
Q=\int \sigma d A
$$

Misalkan muatan $q_{+}$berada pada posisi $x_{0}$, rapat muatan adalah nol di seluruh titik lain, kecuali pada titik $x=x_{0}$ dikarenakan tidak ada muatan pada titik lain kecuali pada titik $x_{0}$. Berdasarkan Gambar 1 , karena $q$ adalah satu-satunya muatan yang berada di dalam pemukaan $A$, maka persamaan (20) dapat dituliskan sebagai berikut:

$$
q=\int \sigma d A
$$

Permasalahan seperti ini sesuai dengan definisi fungsi delta, yakni fungsi yang bernilai nol di semua titik kecuali pada titik asalnya, sehingga persamaan untuk muatan $q_{+}$dapat dituliskan sebagai berikut:

$$
\begin{aligned}
\sigma & =q \delta\left(x-x_{0}, y-y_{0}\right) \\
\int \sigma d A & =\int q \delta\left(x-x_{0}, y-y_{0}\right) d A \\
\int \sigma d A & =q .
\end{aligned}
$$

Fungsi delta pada persamaan (23) menjamin bahwa ketika rapat muatan diintegralkan terhadap luasan, maka total muatan di dalam luasan tersebut sama dengan $q$ sehingga memenuhi persamaan (22). Apabila persamaan (23) disubstitusikan pada persamaan (20) maka diperoleh 


$$
\Delta V=-\frac{q \delta\left(x-x_{0}, y-y_{0}\right)}{\varepsilon_{0}} .
$$

Lambang $x_{0}$ dan $y_{0}$ pada persamaan (24) melambangkan titik asal suatu muatan listrik yang menghasilkan potensial listrik. Gambar 3 menunjukkan letak muatan $q_{+}$pada titik asalnya, oleh karena muatan $q_{+}$berada pada titik $(0,0)$ maka model untuk beda potensial listrik dalam bentuk persamaan diferensial dituliskan sebagai berikut:

$$
\Delta V=-\frac{q \delta(x, y)}{\varepsilon_{0}}
$$

\section{PENUTUP}

Berdasarkan definisi operator Laplace, model untuk beda potensial listrik dalam bentuk persamaan diferensial dan kondisi awalnya adalah sebagai berikut:

$$
\begin{gathered}
\frac{\partial^{2} V}{\partial x^{2}}+\frac{\partial^{2} V}{\partial y^{2}}=-\frac{q}{\varepsilon_{0}} \delta(x, y) . \\
\left.V\right|_{\sqrt{x^{2}+y^{2}} \rightarrow \infty}=\left.\frac{\partial V}{\partial x}\right|_{\sqrt{x^{2}+y^{2}} \rightarrow \infty}=\left.\frac{\partial V}{\partial y}\right|_{\sqrt{x^{2}+y^{2}} \rightarrow \infty}=0 .
\end{gathered}
$$

Persamaan beda potensial listrik ini hanya dapat digunakan untuk mencari beda potensial listrik pada suatu titik yang dihasikan oleh satu muatan listrik saja.

\section{DAFTAR PUSTAKA}

[1]. Abdullah, Mikrajuddin. Fisika Dasar II [monograph online]. Bandung: Institut Teknologi Bandung; 2017 [cited 2019 Mei 26].

[2]. Walker, Jearl, David Halliday dan Robert Resnick. Fundamental of Physics; $10^{\text {th }}$ Edition. USA: John Wiley and Sons Inc; 2014.

[3]. Cain, John W., Angela M. Reynolds. Ordinary and Partial Differential Equations, An Introduction to Dynamical System. Virginia: Commonwealth University; 2010.

[4]. Haberman, Richard. Applied Partial Differential Equations With Fourier Series and Boundary Value Problems; $5^{\text {th }}$ Edition. USA: Pearson Education Inc; 2013.

[5]. Myint-U, Tyn dan Lokenath Debnath. Linear Partial Differential Equation for Scientist and Engineers; $4^{\text {th }}$ Edition. Boston: Birkäuser; 2007.

RESTI JULIA SUSANTI $\quad$ : Jurusan Matematika FMIPA UNTAN, Pontianak restijuliasusanti@student.untan.ac.id

EVI NOVIANI

: Jurusan Matematika FMIPA UNTAN, Pontianak evi_noviani@math.untan.ac.id

FRANSISKUS FRAN : Jurusan Matematika FMIPA UNTAN, Pontianak fransiskusfran@math.untan.ac.id 